\title{
ESTUDO E PREPARO DE HIDROGÉIS DE FIBROÍNA DE SEDA CRIOGELIFICADOS COM COMPORTAMENTO ELÁSTICO
}

\author{
Professora Doutora Marisa M. Beppu (PQ), Professora Doutora Mariana M. Augostine (PQ), Victor \\ Sarti (IC).
}

\section{Resumo}

Os hidrogéis de fibroína são estruturas tridimensionais que apresentam grande potencial como biomaterial na medicina. Nesse trabalho utilizou-se a técnica de criogelificação com diferentes ciclos de congelamento para a modificação das propriedades físicas do material obtendo estruturas macroporosas e um comportamento elástico. Essas novas características incorporadas ao material os tornam objetos de estudo interessantes para atuarem como arcabouços de crescimento de celular.

Palavras Chave: Hidrogel, fibroína, criogelificação.

\section{Introdução}

Os hidrogéis são estruturas tridimensionais de macromoléculas que apresentam propriedades interessantes como material na engenharia tecidual ${ }^{1}$. Tendo em vista essa aplicação, a proteína escolhida para esse estudo foi a fibroína devido as suas propriedades, tais como a biocompatibilidade, biodegradabilidade, facilidade de processamento e mínima reação inflamatória ${ }^{2}$. Entretanto, em algumas aplicações na biomedicina, o material precisa apresentar algumas propriedades como macroporosidade $\mathrm{e}$ comportamento elástico para permeabilidade de células em seu interior.

Com intuito de modificar as propriedades físicas dos hidrogéis, aplicou-se a técnica de criogelificação em diferentes condições de processamento, tais como a temperatura de formação do hidrogel, o tempo em criogenia e o número de ciclos de congelamento e descongelamento.

\section{Resultados e Discussão}

Esse trabalho permitiu a comprovação de que o número de ciclos de congelamento interfere diretamente na conformação física do material como mostrado nas imagens obtidas por Microscopia Eletrônica de Varredura (MEV) da figura 1 .

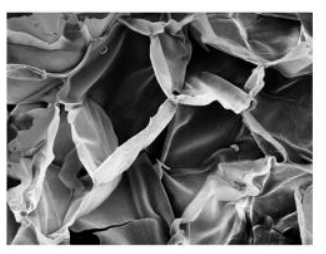

a)

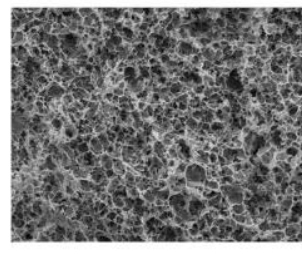

Figura 1. a) Um ciclo de congelamento e descongelamento b) Dois ciclos e c) Três ciclos

A técnica de criogelificação em ciclos permitiu a formação de macroporos de $100 \mu \mathrm{m}$, como mostrado na figura 1, e hidrogéis com propriedades elásticas notáveis.

\section{Conclusões}

A técnica de criogelificação associada ao número de ciclos como parâmetro apresentou influência nas propriedades estruturais das amostras e permitiu a obtenção de hidrogéis macroporosos que podem ser estudados e utilizados como biomateriais na área de engenharia tecidual.

\section{Agradecimentos}

Agradeço à professora Marisa e a professora Mariana pela orientação, ao CNPQ pela oportunidade de pesquisa e à $F E Q$ e à Unicamp pela estrutura.

\footnotetext{
${ }^{1}$ LEE, K. Y.; MOONEY, D. J. Hydrogels for tissue engineering. Chemical Reviews, v. 101, n. 7, p. 1869-1879, Jul 2001.

${ }^{2}$ ALTMAN, G. H. et al. Silk-based biomaterials. Biomaterials, v. 24, n. 3, p. 401-416, Feb 2003.
} 